\title{
Temporal variability of the selected flood parameters in the Biebrza River valley
}

\author{
STEFAN IGNAR ${ }^{1}$, ANNA MAKSYMIUK-DZIUBAN ${ }^{2}$, \\ DOROTA MIROSŁAW-ŚWIĄTEK ${ }^{1}$, JAROSŁAW CHORMAŃSKI ${ }^{1}$, \\ TOMASZ OKRUSZKO ${ }^{1}$, PAWEŁ WYSOCKI ${ }^{1}$ \\ ${ }^{1}$ Department of Water Engineering, Warsaw University of Life Sciences - SGGW \\ ${ }^{2}$ Hydroprojekt Sp. z o.o.
}

\begin{abstract}
Temporal variability of the selected flood parameters in the Biebrza River valley. The paper presents the application of the hydrodynamic one-dimensional model of river flow based on St Venant equations for calculation of annual floods characteristics in the Lower Biebrza River Basin situated in the Northeast of Poland. This model was combined with the Digital Elevation Model (DEM) for determining of area of flooding, its mean depth and flood volume. The model was calibrated using measurements of flood extent and verified comparing calculated flood extent to satellite images. The water level values calculated with the numerical model of flood-flow for cross-sections were next used to determine the digital model of the floodwater table in the valley. Then, inundation extent maps and water depth maps were calculated for whole area of the valley by overlaying the DEM and water table layers. This procedure, flood simulations with the hydrodynamic model and GIS analysis for determinations of inundation extent, was repeated for each day of the analyzed period of 1966-2000. A set of each year maximum calculated areas of flooding with related mean water depths and flood volumes was created and it was submitted to the trend analysis in order to determine possible change tendencies. Statistical analysis of three above described time series of annual flood characteristics was conducted with the use of moving average technique and linear regression method. Moving averages were calculate in two variants: with time step of 5 years and of 10 years. Next, linear trends were calculated by linear regression method. The results
\end{abstract}

indicate that the developed hydrodynamic model of river flow combined with the DEM was useful for the calculation of annual maximum floods in the Lower Biebrza Valley and their parameters. Analysis of calculated flood parameters variability within the analyzed time period of 1961-2000 show decreasing trends for investigated area. This means that results of climate changes are perceptible in investigated area and they form serious danger to riparian wetlands.

Key words: climatic changes, riparian wetlands, hydrodynamic modeling, flood parameters.

\section{INTRODUCTION}

Wetlands are important part of our biosphere serving many valuable ecological and practical functions for people: constitute habitats of many valuable plant and animal species; help maintain biodiversity of plant and animal life; reduce effect of floods; recharge ground waters; provide protection from erosion; improve water quality by filtering out sediment, chemical contaminants or excess nutrients. They also provide recreational and aesthetic capabilities. Despite their usefulness wetlands belong to the most threatened areas due to anthropogenic pressure. In the past, they were treated as 
low economically valued areas and they were destroyed or downgraded by drainage in order to convert into agricultural land or by wasteful exploitation of peat. Also observed climate changes influencing wetland water conditions form serious danger to wetlands. From the other hand wetlands function as sponges and buffer against storms allows for recognizing protection and restoration of them as effective climate adaptation strategies and the loss of wetlands will magnify the impact of climate change.

River feed wetlands conditions depend strongly on occurrence of annual flooding determining development of wetland plants. Basic flooding characteristics determining growth and development of plants are: area of flooding, its mean depth and flood volume. Biebrza Wetlands belong to this category of habitats. Supported by $7000 \mathrm{~km}^{2}$ catchment, the Biebrza River feeds riparian wetlands in its middle and lower course in the area of $150000 \mathrm{ha}$. The inundation of the valley occurs almost every year and it lasts from several weeks to several months. It results from snowmelt or combined snowmelt and rainfall phenomena (Mirosław-Świątek et al. 2004).

Foreseen climate changes leading to global warming and unfavorable changes of rainfall patterns (Liszewska and Osuch 2000) can create serious decrease of spring flooding in riparian wetlands and it would cause diminishing of these valuable habitats. Due to importance of Biebrza Wetlands for nature protection, several researches of environmental parameters variability were conducted in order to find possible symptoms of unfavorable changes due to climate changes. Among others, Maksymiuk et al. (2008) analyzed time series of several meteorological (temperatures, rainfall amounts and snow cover) and hydrological (discharges and water stages) parameters in Biebrza River lower basin, detecting noticeable changes in the most of analyzed meteorological parameters and less observable tendencies in analyzed hydrological parameters. No direct flooding characteristics influencing riparian wetlands conditions were analyzed and the objective of this study is to analyze possible change tendencies of annual flood characteristics: area of flooding, its mean depth and flood volume.

\section{MATERIAL AND METHODS}

The studied area of the Biebrza river valley is situated in the Northeast of Poland and designated as a wetland site of a global significance, which is under protection of Ramsar Convention. The study area, the Lower Biebrza Basin is an ice-marginal valley where the floodplain (21000 ha) is a predominant morphologic structure covered by mosaic of marshy vegetation starting from sedge, sedgemoss and reed communities to willow shrubs, black alder forest, swampy birch and peat coniferous forest. The most valuable ecosystems here are not only natural areas of peatlands but also large areas of open semi-meadows, which are the result of extensive agriculture use. The hydrogenic dependent habitats in the Biebrza marshes run on a stable ground water inundation or river flooding which occurs regularly and reinforce these representative water ecosystems every year. Changes of water conditions and discontinuance of extensive agriculture causes transformation of meadows and 
pastures into less valuable habitats like tall herb vegetation or reed.

Hydrodynamic model of river flow was applied for Biebrza River in order to determine annual floods extends. Unsteady flow in natural rivers is usually treated as a one-dimensional flow in practice and it is based on St Venant equations (Liggett and Cunge 1975). In order to simulate flood flow in the lower Biebrza Basin, the one-dimensional unsteady model flow RIVER-SV was applied (Mirosław-Świątek et al. 2006; Chormański et al. 2009). The model simulates the Lower Biebrza River as a single channel starting from Osowiec gauge (cross-section bd1) and terminating at cross-section bd17 - Burzyn gauge (Fig. 1). This model can be used as a simplified description of flow resistance expressed by the spatially differentiated Manning's coefficient or the Darcy-Weisbach relationship with the introduction of a water mass and momentum exchange process between the main channel and the floodplains and parts of a cross section covered with vegetation and those with no vegetation (Mirosław-Świątek et al. 2006). In this simulation the friction factors are described by the spatially differentiated Manning's coefficients (Chormański et al. 2004). Field monitoring in the Lower Biebrza Basin proves that during flood periods, the river valley consists of parts which mainly act as storage for flood water and of active flow areas (Chormański and Mirosław-Świątek 2006). The 1D model is capable of describing flood conditions using the appropriate geometry of cross-sections, which are limited to the flow active zones. In the model developed, the particular areas for each cross-section were identi- fied according to a vegetation map and topography determined with the Digital Elevation Model (DEM) (Okruszko T. et al. 2006). The DEM of the Lower Basin was elaborated with ArcGIS ${ }^{\circledR}$ as a raster representation of the floodplain morphology and validated with a survey (Chormański 2003).

In order to objectively evaluate model performance, the most commonly employed error measure, such as the root mean square error (RMSE), was computed for calculated and observed discharge hydrographs at downstream cross-sections in spring 1999. The maximum discharge value was $184 \mathrm{~m}^{3} \cdot \mathrm{s}^{-1}$ for this flood event. The value of RMSE of $10.4 \mathrm{~m}^{3} \cdot \mathrm{s}^{-1}$ indicates that the model reproduces well the natural flood event at downstream boundary conditions (the Burzyn gauge). Congruent model results with discharge rates at the downstream boundary condition does not mean that the model developed correctly reproduces water levels upstream from the Burzyn gauge. The flooded area calculated with the model was $20 \%$ larger than the flood extent estimated during field measurements on 03.19.1999. The model validation throughout the valley during this flood event was elaborated with the help of processed Landsat satellite images. The comparison of the inundated area generated by the hydraulic model coupled with DEM and obtained with the remote sensing method indicates that the quality of the model is good for flood events (Mirosław-Świątek and Chormański 2007). The flooded area calculated with the model for 17.03 .2002 was $76.36 \mathrm{~km}^{2}$ while the flooded area determined with remote sensing was $66.42 \mathrm{~km}^{2}$, which is a difference of $13 \%$. 


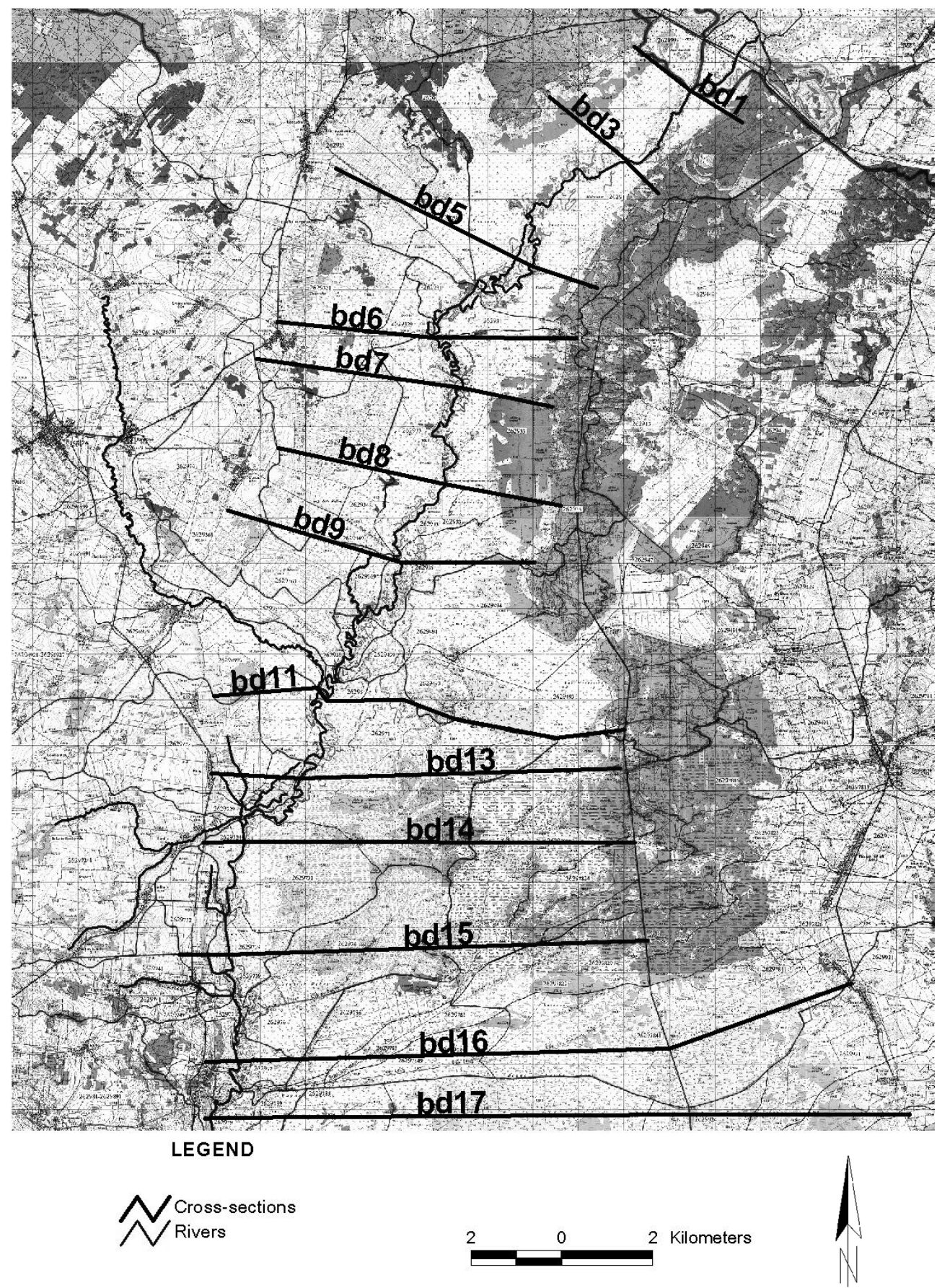

FIGURE 1. The cross-sections localization in the Lower Biebrza Basin 
The water level values calculated with the numerical model of flood-flow for cross-sections were next used to determine the digital model of the floodwater table in the valley. Then, inundation extent maps and water depth maps were calculated for whole area of the valley by overlaying the DEM and water table layers. This procedure, flood simulations with the hydrodynamic model and GIS analysis for determinations of inundation extent, was repeated for each day of the analyzed period of 1966-2000 due to available hydrologic data. A set of each year maximum calculated areas of flooding with related mean water depths and flood volumes was created and next it was submitted to trend analysis in order to determine possible change tendencies.
Statistical analysis of three above described time series of annual flood characteristics was conducted with the use of moving average technique and linear regression method. Moving averages were calculate in two variants: with time step of 5 years and of 10 years. Next, linear trends of were calculated by linear regression method.

\section{RESULTS AND DISCUSSION}

The above described developed hydrodynamic model of river flow was applied for calculation of annual floods in the Lower Biebrza River Basin. Results show relatively wide variability of calculated maximum flood parameters for respective years. Maximum flood area

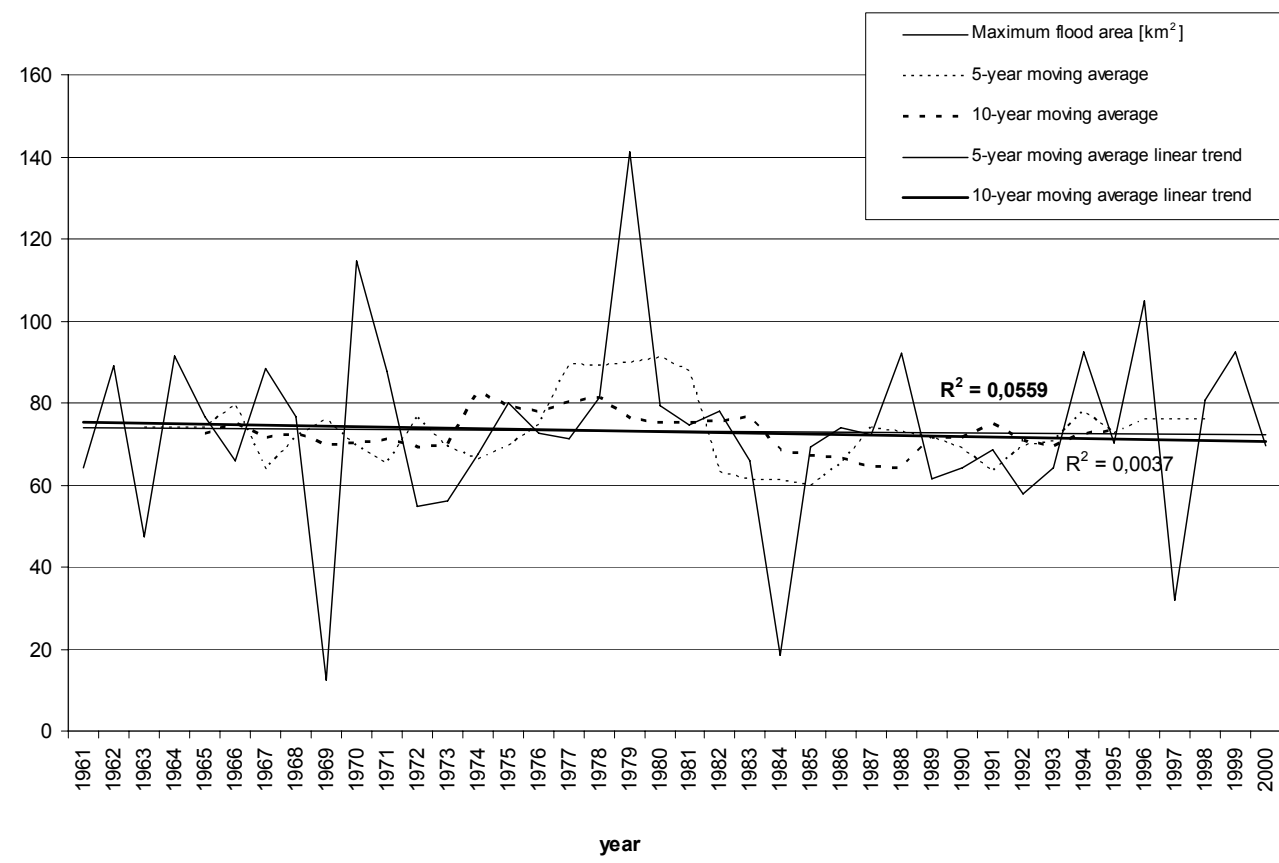

FIGURE 2. Trends of change of calculated maximum annual flood area in the Lower Biebrza Basin in the period of 1961-2000 


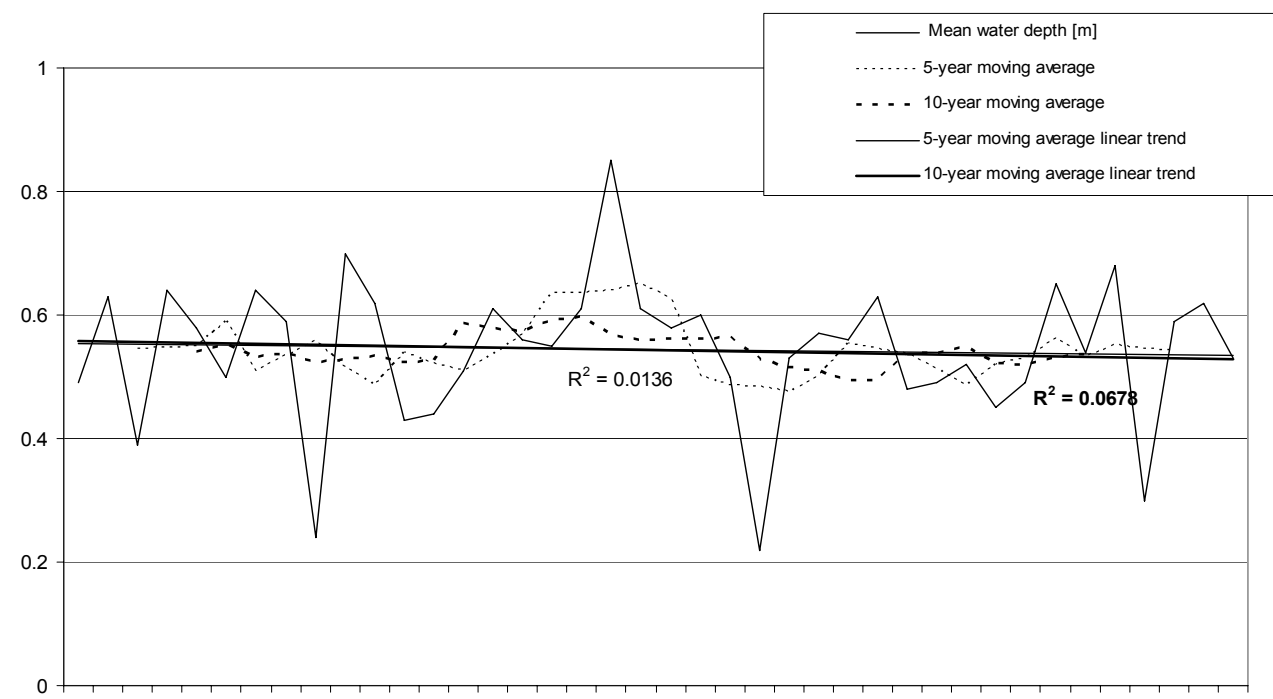

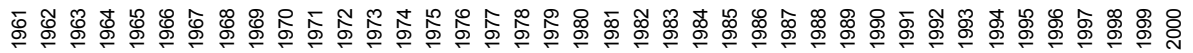

year

FIGURE 3. Trends of change of calculated mean water depth of the maximum annual flood in the Lower Biebrza Basin in the period of 1961-2000

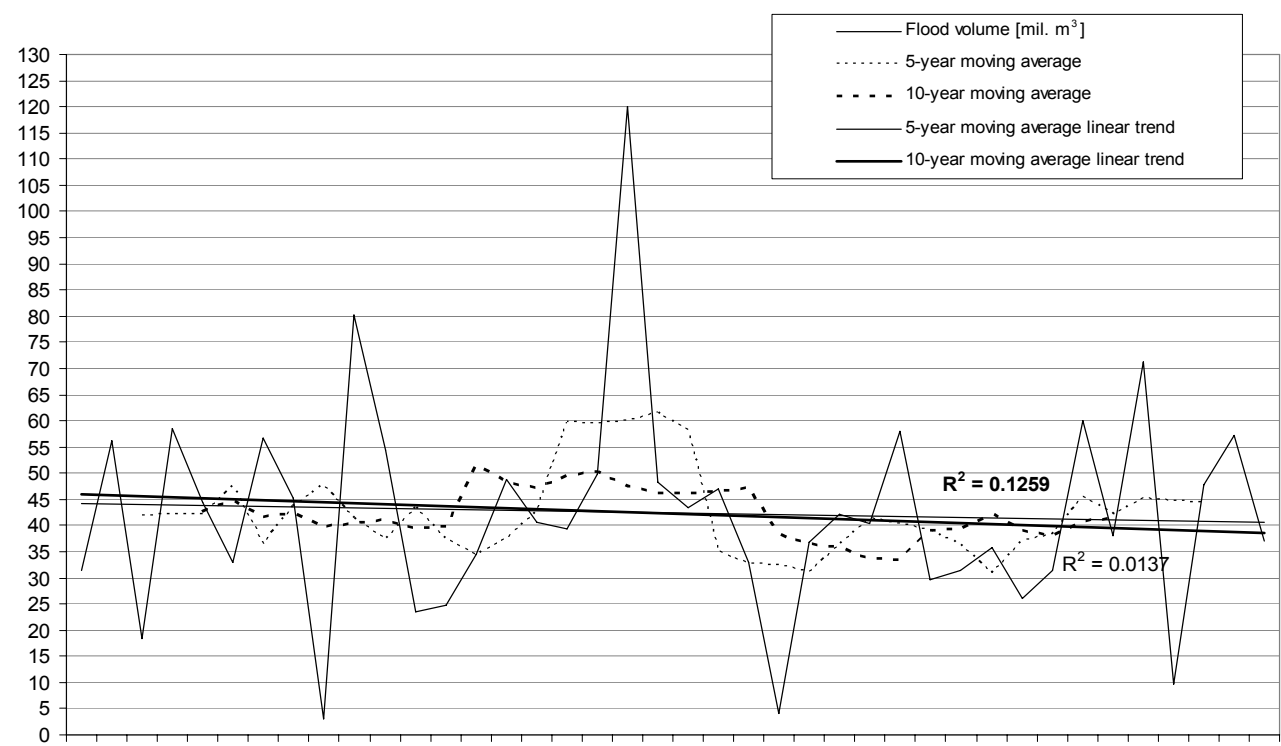

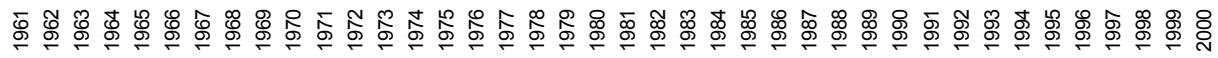

year

FIGURE 4. Trends of change of calculated maximum annual flood volume in the Lower Biebrza Basin in the period of $1961-2000$ 
changes within the interval from 12.50 $\mathrm{km}^{2}$ to $141.21 \mathrm{~km}^{2}$, mean water depth from $0.24 \mathrm{~m}$ to $0.85 \mathrm{~m}$ and flood volume from $3000000 \mathrm{~m}^{3}$ to $120028000 \mathrm{~m}^{3}$. Time series of three flood characteristics together with results of processing by moving average techniques and with trend lines calculated by linear regression method are presented respectively in the Figures 2, 3 and 4 . These figures show the parameters variability within analyzed time period together with calculated linear trends. Presented diagrams show decreasing trends of annual floods in the Lower Biebrza Basin.

\section{CONCLUSIONS}

Obtained results indicate that developed hydrodynamic model of river flow combined with the Digital Elevation Model was useful for the calculation of annual maximum floods in the Lower Biebrza Valley and their parameters. Analysis of calculated flood parameters variability within the analyzed time period of 1961-2000 show decreasing trends for investigated area. This means that results of climate changes are perceptible in investigated area and they form serious danger to river feed wetlands.

\section{REFERENCES}

CHORMAŃSKI J. 2003: Methodology for the flood extent determination in the Lower Biebrza Basin. Ph.D. thesis, Warsaw Agricultural University, Warsaw, p. 186.

CHORMAŃSKI J., MIROSŁAW-ŚWIĄTEK D., OKRUSZKO T. 2004: Remote Sensing limitation in flood modeling verification in wetlands. [In:] Kubrak J., Okruszko T., Ignar S. [Eds]. Model application for wetlands hydrology and hydraulics. Warsaw Agricultural University Press, Warsaw, 51-72.
CHORMAŃSKI J., MIROSŁAW-ŚWIĄTEK D. 2006: Monitoring of the spring flood in the Lower Biebrza Basin, Polish J. Environ. Stud., vol. 15, No 5D, 122-126.

CHORMAŃSKI J., MIROSŁAW-ŚWIĄTEK D., MICHAŁOWSKI R. 2009: A hydrodynamic model coupled with GIS for flood characteristics analysis in the Biebrza riparian wetland. Int. J. of Oceanography and Hydrobiology. Vol. XXXVIII No 1, 1-8.

LIGGETT J., CUNGE J. 1975: Numerical Methods of Solution of the Unsteady Flow Equations. [In:] Mahmood K., Yevjevich V. [eds]. Unsteady Flow in Open Channels, Water Resource Pub., Fort Collins, CO, U.S.A. Vol. I, Chap. 4. p. 102.

LISZEWSKA M., OSUCH M. 2000: Analysis of results of global climate models for Central Europe and Poland. Geogr. Polon. 73, 49-63.

MAKSYMIUK A., FURMAŃCZYK K., IGNAR S., KRUPA J., OKRUSZKO T. 2008: Analiza zmienności parametrów klimatycznych i hydrologicznych w dolinie rzeki Biebrzy. [Analysis of climatic and hydrologic parameters variability in the Biebrza River basin]. Przeglad Naukowy Inżynieria i Ksztaltowanie Środowiska, z. 3 (41), 69-77 [Engl. summ.].

MIROSŁAW-ŚWIĄTEK D., OKRUSZKO T., CHORMAŃSKI J. 2004: Natural floodplain storage capacity - modelling approach. J. Water Land Dev. No 8, 76-86.

MIROSŁAW-ŚWIĄTEK D., KUBRAK J., CHORMAŃSKI J. 2006: Steady 1 D water surface model of natural rivers with vegetated floodplain: An application to the Lower Biebrza. Proceedings of the International Conference on Fluvial Hydraulics River Flow, Vol. 1, 545-553.

MIROSŁAW-ŚWIĄTEK D., CHORMAŃSKI J. 2007: Verification of the numerical river flow model by use of remote sensing. [In:] Okruszko T., et al. [eds]. Wetlands: Monitoring, Modelling, Management. Taylor \& Francis Group, London, 173-180.

OKRUSZKO T., CHORMAŃSKI J., MIROSŁAW-ŚWIĄTEK D. 2006: Interaction between surface and groundwater in the flooding of riparian wetlands: Biebrza wetlands case study.[In:] Demuth S., Gustard A., Planos E., Scatena F., Servat E. [eds]. Climate Variability and Change - Hydrological Impacts. FRIEND Conference in Havana, Cuba, International 
Association of Hydrological Sciences Press, 573-578.

Streszczenie: Czasowa zmienność wybranych parametrów wezbrań $w$ dolinie rzeki Biebrzy. $\mathrm{W}$ artykule przedstawiono zastosowanie jednowymiarowego hydrodynamicznego modelu przepływu w rzece bazującego na równaniach Saint Venanta do obliczenia charakterystyk maksymalnych rocznych zalewów rzecznych w basenie dolnej Biebrzy, usytuowanym w północno-zachodniej Polsce. Model ten został połączony z Numerycznym Modelem Terenu (NMT) dla wyznaczenia zasięgu zalewu, jego średniej głębokości i objętości. Model został skalibrowany z wykorzystaniem pomiarów zasięgu zalewu i zweryfikowany poprzez porównanie obliczonego zasięgu zalewu ze zdjęciami satelitarnymi. Rzędne zwierciadła wody obliczone modelem numerycznym przepływu dla przekroi poprzecznych były dalej użyte do wyznaczenia cyfrowego modelu zwierciadła wody w dolinie. Następnie mapy zasięgu zalewu i mapy jego głębokości zostały obliczone dla całego obszaru doliny poprzez nałożenie NMT i warstw zwierciadła wody. Ta procedura, obliczanie wezbrań przy pomocy modelu hydrodynamicznego i analiza GIS dla określenia zasięgu zalewu, została powtórzona dla każdego dnia w analizowanym okresie 1961-2000. Utworzony został zbiór maksymalnych rocznych zasięgów zalewu wraz z odpowiadającymi im średnimi głębokościami i objętościami wezbrania, który został poddany analizie trendów w celu określenia możliwych tendencji zmian. Przeprowadzona została analiza statystyczna trzech powyżej opisanych serii czasowych charakterystyk rocznych wezbrań $\mathrm{z}$ zastosowaniem techniki średnich ruchomych i analizy regresji. Średnie ruchome obliczono dla dwóch wariantów: $z$ krokiem czasowym 5 lat i 10 lat. Następnie obliczono trendy liniowe metoda regresji liniowej. Uzyskane rezultaty wykazały, że opracowany hydrodynamiczny model przepływu w rzece połączony z NMT był przydatny do obliczania maksymalnych rocznych zalewów rzecznych w basenie dolnej Biebrzy i ich charakterystyk. Analiza zmienności obliczonych parametrów wezbrania dla okresu 1961-2000 wykazała istnienie trendów malejących dla badanego obszaru. Oznacza to, że rezultaty zmian klimatycznych są zauważalne w badanym obszarze i stanowią one poważne zagrożenie dla mokradeł przybrzeżnych.

Slowa kluczowe: zmiany klimatu, mokradła przybrzeżne, modelowanie hydrodynamiczne, parametry wezbrań.

\section{MS. received 30 November 2011}

\author{
Author's address: \\ Stefan Ignar \\ Katedra Inżynierii Wodnej \\ Szkoła Główna Gospodarstwa Wiejskiego \\ ul. Nowoursynowska 159 \\ 02-776 Warszawa \\ e-mail: stefan_ignar@sggw.pl
}

